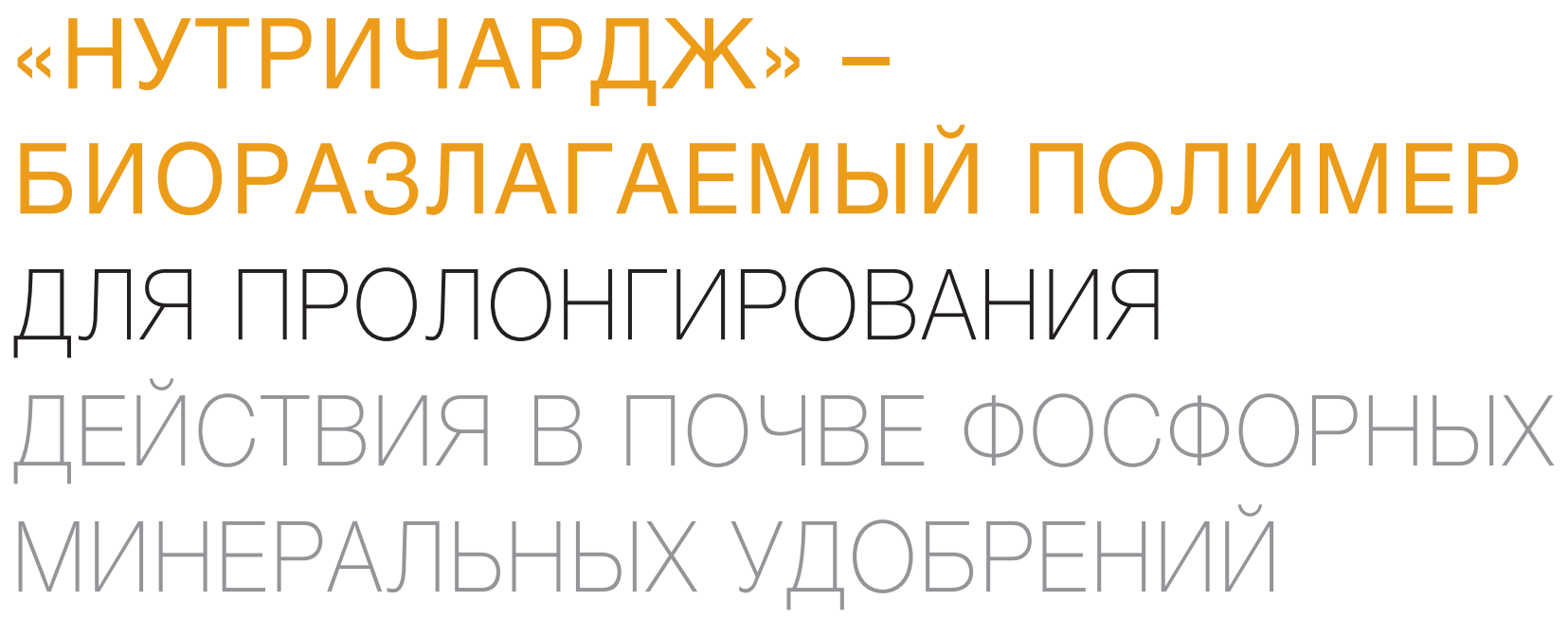

\title{
NUTRICHARGE - BIODEGRADABLE POLYMER TO PROLONG THE ACTION OF PHOSPHOROUS AND MINERAL FERTILIZERS IN THE SOIL
}

Хромов С.М. - генеральный директор,

магистр аграрной экономики

О०० "Иглус"

142116, Россия, Московская обл., г. Подольск, ул. Лобачева, д. 13

E-mail: info@igloos.ru

http://igloos.ru/

В данной статье мы поднимаем проблему низкой эффективности сложных минеральных удобрений, фиксации фосфора в почве металлами и его недоступности для растений в течение сезона.

Ключевые слова: фосфорные минеральные удобрения, биоразлагаемый полимер, пролонгированное действие.
Khromov S.M.

Igloos LLC

142116, Russia, Moscow region, Podolsk, Lobacheva str., 13 E-mail: info@igloos.ru

http://igloos.ru/

We pose a problem of low efficiency of complicated mineral fertilizers, phosphorus fixation by metals and its inaccessibility for plants during the season.

Keywords: phosphorous mineral fertilizers, biodegradable polymer, prolonged action.
США уже давно широко известна информация о том, что фосфор как важнейший и достаточно дорогой элемент питания растений при попадании в почву в виде минеральных удобрений имеет очень низкий процент доступности из-за реакции с металлами и выпадения в водонерастворимый осадок. От 75 до 95\% фосфора блокируется в почвенном растворе в нерастворимой форме, и он уже не доступен растениям (Mortvet, 1994).

Часто цвет листьев растений показывает, что они испытывают десицит фосфора, хотя в анализе почвы уровень фосфора кажется агроному достаточным.

Реакцию фосфора с металлами в почвенном растворе легко продемонстрировать несложным химическим опытом. Мы берем две прозрачные баночки с водой. Добавляем в каждый жидкий кальций имитируя щелочную почву с высоким уровнем кальция (в кислых почвах основным металлом, связывающим фосфор

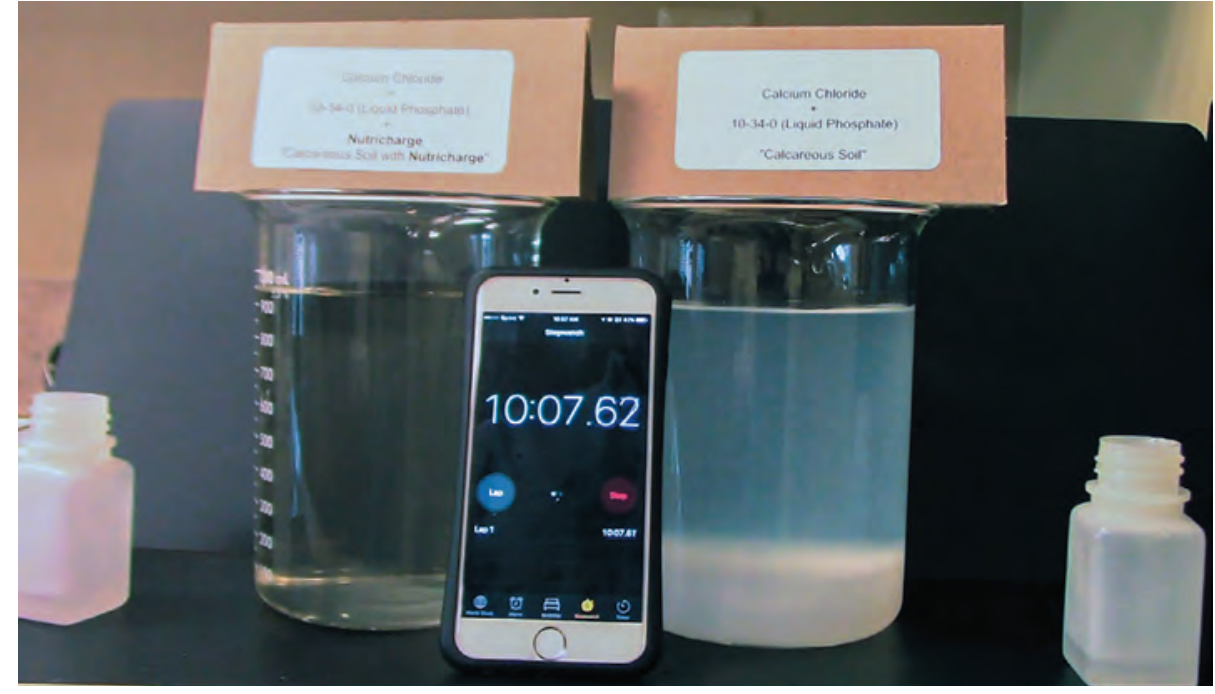

будет алюминий). Затем в правую баночку мы добавляем жидкое фосфорное удобрение. Сразу начинается химическая реакция - в результате выпадение белого осадка, который уже через короткое время (10 минут) очень хорошо заметен. В левую баночку мы добавляем жидкое фоссрорное удобрение с небольшим количеством биополимера Нутричардж (1\%), который имеет слегка коричневый оттенок, однако реакции выпадения белого осадка не начинается, фосфор не вступил в реакцию с кальцием и остался доступен растениям в растворе (рис.1). 
Что такое «Нутричардж» и как он работает?

Фосфор попадает в почву с отрицательным зарядом, а все металлы, находящиеся в почве, имеют положительный заряд. Происходит простая химическая реакция, в результате которой фоссор выпадает в осадок. Молекула биополимера Нутричардж имеет большую молекулярную массу с большим отрицательным зарядом, таким образом она максимально притягивает катионы металлов на себя (рис.2), оставляя фосфор с более слабым отрицательным зарядом в почвенном растворе не связанным. Основой биополимера является аминокислота, которая в течение 90-120 дней в зависимости от условий в почве утилизируется почвенными бактериями, за счет этого полимер является безопасным и не накапливается ни в растениях, ни в почве.

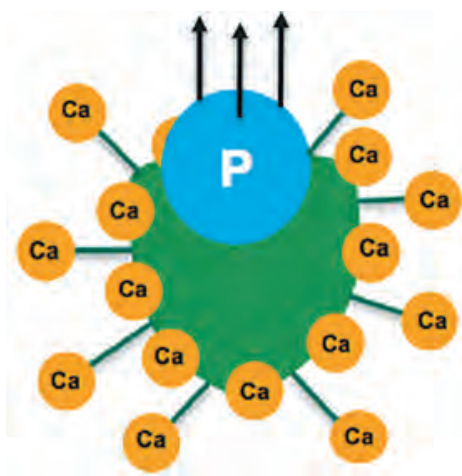

Рис. 1. Зеленая молекула биополимера Нутричардж притягивает катионы кальция.

Какие результаты могут получить предприятия, применяя

Нутричардж

В 2016 году компания ИГЛУС провела производственные опыты в центральном регионе, охватив предприятия в Тульской, Рязанской, Брянской, Орловской, Московской и Владимирской областях. Общая площадь посевов с применением биополимера Нутричардж составила 1000 га.

Испытания были проведены на основных культурах региона: озимой и яровой пшенице, кукурузе на силос, многолетних травах, картофеле, овощах открытого грунта (морковь, капуста, свекла столовая), а также на сое, рапсе и сахарной свекле.

Сразу отметим, что все опытные поля показали существенную прибавку урожайности, по сравнению с контролем. Затраты на полимер в расчете на 1 га составили порядка 1100 руб. при дополнительной прибавке урожая от 3000 до 20000 руб. с 1 га.

Фоссоор положительно влияет прежде всего на корневую систему растения. И чем больше фосфора было доступно растению в течение вегетационного периода, тем выше урожайность мы получим. «Нутричардж» решает задачу пролонгации действия фосфора в почве и тем самым способствует повышению урожайности.

Предприятие может снизить нагрузку на почву, снизив норму внесения минеральных удобрений на 20\%, применяя биополимер Нутричардж. Вложения на 1 га не изменятся, но за счёт прибавки урожая, снизится себестоимость. Теперь данный инструмент доступен не только американским, но и российским производителям.

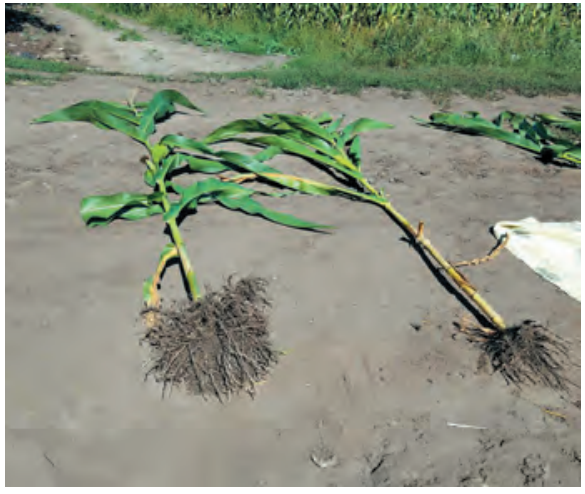

Кукуруза на силос в Брянске, прибавка 40 ц.

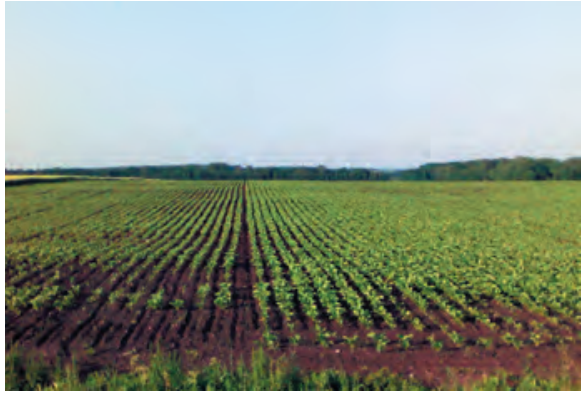

Сахарная свекла в Орловской области, прибавка 60 ц.

По вопросам, связанным с биополимером Нутричардж, обращайтесь в компанию «Иглус».

www.igloos.ru - раздел удобрения.

Агрономическая служба: +7(925) 010-28-68, chebanenko@igloos.ru

Коммерческий отдел: +7(925) 505-09-89, khromov@igloos.ru

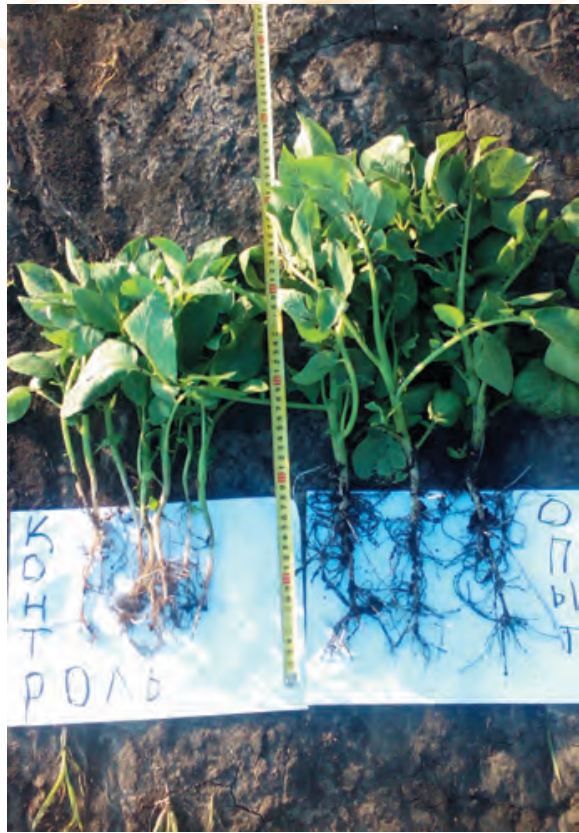

Картофель в Брянской обл., прибавка 20 ц.

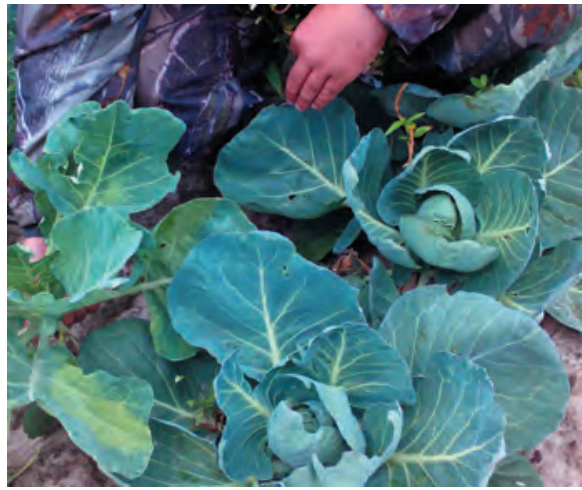

Капуста сорта «Таурус», СПК «Илькино»,

Владимирская обл., прибавка урожая 30 ц/га.

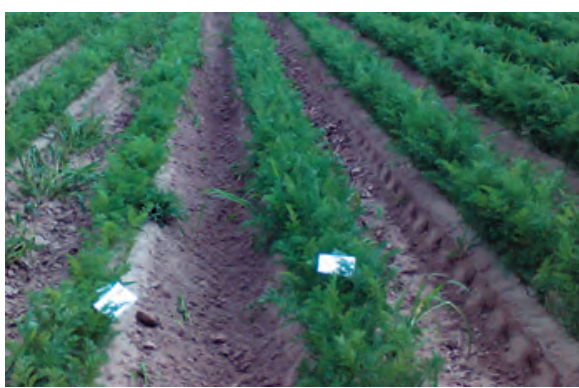

Морковь сорта «Балтимор», СПК «Илькино», Владимирская обл., прибавка урожая 50 ц/га. 